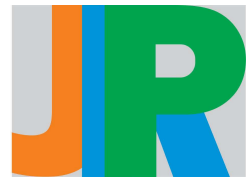

\title{
The Effect of Using The Manual of Collaborative Teaching Approach to Mastering the Basic Standard of Writing Malay Language
}

\author{
Mohd Asnorhisham Adam ${ }^{1 *}$, Sanitah Mohd Yusof ${ }^{2}$, Abdul Rahim Hamdan³, \\ ${ }^{1}$ Collaborative Learning Centre of Literacy and Numeracy, Pasir Gudang District Education Office, Johor, Malaysia \\ ${ }^{2}$ School of Education, Faculty of Social Sciences and Humanities, Universiti Teknologi Malaysia, Johor, Malaysia \\ ${ }^{3}$ Faculty Human Development, Sultan Idris Education University, Perak, Malaysia \\ ${ }^{*}$ Corresponding author: asnorhisham@gmail.com
}

\begin{abstract}
The study was conducted to examine the effectiveness of the Collaborative Teaching Approach Manual (CTAM) on the mastery of the basic standard of literacy writing Malay language level one. The study was conducted by quasi-experiment using CTAM in teaching and facilitating. This study was conducted in Primary School in Pasir Gudang district which involved a sample of 70 students in year two. The two teachers involved were Remedial Teacher and Malay Teacher in this study. The t-test is used to test the hypothesis of the study. The findings showed that there was a significant difference to the experimental group using CTAM in achieving the overall basic standard of literacy writing Malay language students. The findings show that the use of CTAM is able to increase the level of literacy mastery more effectively to the pupils.
\end{abstract}

Article Information:

Received: $25^{\text {th }}$ March 2019

Revised: $10^{\text {th }}$, Aug 2019

Accepted: $2^{\text {nd }}$ Sep 2019

\section{Introduction}

The increasingly challenging education curriculum in Malaysia urges teachers to change in tandem with the goals and targets of change. Teachers now need to take proactive and collaborative action by sharing information in fulfilling mandated duties and responsibilities. In pedagogy, when two or more teachers share a lesson on a group of students in one of the same classes known as collaborative teaching (Cramer, 2010). In collaborative teaching, teachers share ideas or information, provide moral support and encouragement when faced with difficulties either personally or professionally. Collaborative teaching improves the effectiveness and creativity of the two united people's minds. Teachers do not work alone, instead, refer to each other to get ideas for progress or improvement of $\mathrm{T} \& \mathrm{~F}$.

According to (Laila Hairani, 2008; Mohd Asnorhisham Adam \& Abdul Rahim Hamdan; 2017) collaborative teaching combines the strengths, beliefs, and expertise of teachers who can help them meet the challenges of reform or better change. In addition, collaborative teaching is a professional source of learning through friendship and sincerity of colleagues. Collaborative among teachers is a powerful mechanism for teachers to look at their own teaching and learning practices (Bailey, 1996; Mohd Asnorhisham \& Abdul Rahim, 2016). Collaborative planning encourages the creation of creative and innovative thinking. Produced products are better than those produced alone. Collaborative in the classroom provides an opportunity for each teacher to observe 'one model' being taught. Collaborative teaching approaches are one of the best ways to integrate students with special needs in the mainstream education system (Zamri Mahamod, 2012). Collaborative teaching on the basic standard of Malay literacy means collaborative collaboration between teachers for the success of $T \& F$ activities including the support and guidance of administrators and counseling officers to achieve the goals and goals known as collaborative teaching approaches.

The basic standardization of literacy is crucial in order for literate and subsequently successful students in education (Diamond \& Karen E, 2012). Literacy and Numeracy Program (LINUS) was introduced in August 2009. The implementation of the LINUS program targets $100 \%$ of year 3 students to master literacy and numeracy skills before the fourth year of 2013, except for special needs students.

Full literacy of basic literacy and numeracy basic skills becomes a very important foundation in the quest for good human capital with knowledge, thinking skills, leadership skills, bilingual, ethical and spiritual skills as well as national identity as expected in the Malaysian Education Blueprint 2013- 2015 through pre-school education until the middle of last (MOE, 2015).

The problem of basic standardization of writing among pupils still exists either in primary or secondary school. One of the factors identified is the teacher. Teacher factor is the most important factor in ensuring the basic standard of literacy of pupils. Although the effective $\mathrm{T} \& \mathrm{~F}$ process is the result of teachers, pupils, classes and schools (Dunkin, M.J. \& Biddle, B.J., 1974) but teacher factors dominate other factors.

Writing is an interactive process between the text and the imagination of the reader. Therefore, teachers need to diversify teaching writing techniques to make T\&L more varied, attractive and 
can create students' interest in learning more diligently (Zamri Mahamod, 2012). Students of varying levels of heterogeneity and heterogeneous require differentiation in T\&L. Students who have just mastered the basic standard of writing Malay in the first level require remediation, reinforcement, and enrichment in the mainstream class. The remediation, reinforcement and enrichment exercise is a continuation after these students successfully undergo a special remediation program and the LINUS program.

\section{Statement of Problem}

In this article, we identify dimensions of customer-based corporate reputation and develop scales to measure these dimensions. The problem of mastery of basic Malay language standards among primary school pupils still exists and guiding even though various programs have been implemented. According to MOE (2017), the achievement of the basic standard Malay language students through the LINUS program has declined from 2012 to 2017 with a record of 8965 students who are not master. In addition, even though this pupil has mastered but still weak and left behind in the KSSR mainstream curriculum following his 3-year schooling. There are also students who are literate but inconsistent and have to be restored by MT or RT. The cause of the problem is that the student can not be adequately guided by the MT (Mohd Asnorhisham Adam \& Abdul Rahim Hamdan, 2016, 2017).

MT Guidance in T\&F is essential to the preservation of basic Malay language standards. According to the study (Mohd Asnorhisham Adam et al., 2017; 2018), it is difficult for MT to carry out differentiation in the classroom due to a large number of pupils. The number of students in a class after being grouped through streaming class has become a source of difficulty for teachers to implement T\&F and to work on the basic standardization of the students' standardized Malay language. MT is unable to perform remediation, reinforcement and enrichment activities when there is a large number of pupils in the mainstream class up to 40 students in a class. MT is difficult to carry out T\&F when it comes to the diversity of student-level diversity. MT is also difficult to manage pupil behavior well because it can not identify the problem and the level of pupil control. MT also has difficulty in implementing bridging in regular classes. In addition, the teacher who rehabilitated the pupil immediately did not collaborate, discuss, share and work with the team to work on these students to master language skills.

Implications of these factors, teachers feel overwhelmed and depressed as they can not recover pupils well. In addition, teachers with less training and uncertainty with the implementation of LINUS and Special Remediation Programs contribute to teacher pressure. This, coupled with no problem sharing with friends or attention of administrators. Hence, an approach should be specifically tailored to the teaching of teachers to overcome problems in the diversity of domination and the number of students in a single class.

\section{Objective}

The purpose of this study is to examine the effect of the use of the Collaborative Teaching Approach Manual on the mastery of the basic standard of literacy writing Malay language level one. Additionally, through this approach to achieve the level of mastery of the 12 basic standard constructs of Malay literacy students through the standard Malay language literacy screening of the Ministry of Education Malaysia. This study is also to answer the question of study whether there is a difference in the mastery of Malay literacy writing in the pre and post-test stage between conventional teaching approaches with collaborative teaching approaches with the use of CTAM.

\section{Methodology}

In this article, we identify dimensions of customer-based corporate reputation and develop scales to measure these dimensions. This study uses a quasi experimental and descriptive design using quantitative methods. The t-test quantitative method was used to obtain data on the mean difference in mean year 2 pupils. Both control and experimental groups were given pre-test before the study was conducted, while the post-test was given at the end of the study. The researcher also collected quantitative data on pre and post-test of student performance difference in T\&F. Two classes of students were selected as a sample of the study. A class uses collaborative teaching approaches (experiments) while one class uses conventional teaching (control) approaches.

This study involved 70 years two students, comprising of 33 control group students and 37 experimental groups. All pupils have a feature that still has not mastered 12 constructs of Malay literacy. The researcher reviewed the problems that led the pupils to not mastered 12 constructs of Malay literacy through pre-test, observation, and interview. Different class observations are performed on teachers and students in T\&F sessions. In addition, document revisions are also conducted based on two (2) or final Malay literacy screening instruments, 2017 as well as the Student's Reporting Disclosure Form (BPPI). This filter instrument has been provided by the Malaysian Examination Board. Pre and post trials were conducted using a year two screening instrument 2017.

The study takes a month involving two teachers comprising an MT and an RT. The concept of collaborative teaching approaches involves two teachers namely MT and RT. This approach is based on a model introduced by Cook and Friend (2010) where T\&F occurs in the same class.

This study received cooperation and support from FasiLINUS Officers (Malay Language), District Education Office acting as counselors. Prior to implementing this approach, teachers will discuss with FasiLINUS officers and administrators from various aspects of management and T\&F such as the current status of student mastery, data analysis of constituents, issues, and background of students. In this study, four times counseling was given to the teacher within one month. With this collaborative teaching approach, RT and MT can share the task of delivering Malay language content more interestingly and effectively. In addition, the implementation of remediation, reinforcement, and enrichment can also be achieved.

\section{Results \& Discussion}

This section presents the profiles of study students from the background to obtaining sufficient data. The research student consists of year two (2) students in 2018. The sample of the study also comprises students who have not mastered the basic standard of literacy writing Malay. The total number of pupils of quantitative study was 70 pupils, divided into 37 pupils with a collaborative teaching approach or experimental group and 33 pupils with conventional teaching or control approaches. Table 1 shows the sample profiles of quantitative studies.

Table 1: Quantitative Study Sample Profile

\begin{tabular}{llllll}
\hline & & & \multicolumn{2}{l}{ Sex } & \\
\cline { 3 - 5 } No & Group & Year & Male & Female & Total \\
$\mathbf{1}$ & Control & 2 & 29 & 4 & 33 \\
$\mathbf{2}$ & Experiment & 2 & 28 & 9 & 37 \\
\multicolumn{2}{l}{ Total } & & 57 & 13 & 70 \\
\hline
\end{tabular}

Table 2 shows the total number of pupils of the control group of 33 people consisting of 4 girls and 29 male students. The students of the experimental group consisted of 37 students comprising 9 girls and 28 male students. The ages of both groups are eight (8) years. Based on the current decision of Malay literacy screening, this group did not master literacy in Malay. MOE (2015) has set a disciple who does not care for all 12 constructs or one of the constructs in the filter is categorized as non-controlling. Therefore these two groups are homogeneous. 
Table 2: Min Control And Experiment Group Min Achievements At PreTest Levels Based On Conventional And Collaborative Teaching Approach

\begin{tabular}{lllll}
\hline Group & N & Mean & $\begin{array}{l}\text { Standard } \\
\text { Deviation }\end{array}$ & P-Value \\
\hline Control & 33 & 20.15 & 15.18 & 0.152 \\
Experiment & 37 & 16.06 & 18.40 & \\
\hline
\end{tabular}

Table 3: Min Control And Experiment Control Minutes At The Post Test Level Based On Conventional And Collaborative Teaching Approach

\begin{tabular}{lllll}
\hline Group & N & Mean & $\begin{array}{l}\text { Standard } \\
\text { Deviation }\end{array}$ & P-Value \\
\hline Control & 33 & 35.15 & 18.92 & 0.000 \\
Experiment & 37 & 47.83 & 17.18 & \\
\hline
\end{tabular}

Table 3 shows the mean achievement between the control group and the experiment at the post-test level with conventional and collaborative teaching approaches. From the findings there were 2 groups of students analyzed. The control group was 33 students while the experimental group was 37 students. In the control group pupils category, the mean score was 35.15 and the deviation was 18.92 . The experimental group, however, recorded a mean score of 47.83 with a typical deviation of 17.18. From that analysis, t-test scores 0.00 . This shows that there is a significant difference in the mean achievement between control and experimental groups at the post-test stage in conventional and collaborative teaching approaches.

\section{Conclusion}

In this article, we identify the effect of this collaborative teaching approach is that teachers are able to manage students' class and behavior well in T\&F activities. In addition, teachers are more focused and able to guide students more effectively. When problems arise in management aspects and the $\mathrm{T} \& \mathrm{~F}$ teacher will discuss and share collaboratively in finding the best solution to achieve goals and targets. Pupils are more interested in learning as well as facilitate teachers to carry out remediation, reinforcement, and enrichment. The teachers involved in this study agreed that this collaborative teaching approach was effective in improving the mastery of Malay literacy level one. CTAM is an innovation of teaching methods that can better manage student diversity in education. The effectiveness of the CTAM is dependent on the involvement and role of all parties as a whole and in co-operation with them. The impact of such diverse pupils for the mastery of the basic standard of Malay literacy or other subjects can prevent them from dropping out of education.
During the process of collaborative teaching approaches, sharing of information between all parties is very important in order to prevent students from being dropped during the T\&F process. Discussions are also important to get more information and avoid making assumptions in the process of collecting student information and all decisions are made together.

\section{References}

Adam, Mohd Asnorhisham, Hamdan, Abdul Rahim, Salim, Noraini, and Jamian, Jaafar. 2017. "Enhancing Malay Language Literacy Proficiency Through Collaborative Teaching Approach." Serials Publications 97 (12): 21-29.

Bahagian Pembangunan Kurikulum (2015). Buku Pengoperasian LINUS2.0.Kementerian Pendidikan Malaysia.

Bailey, F.(1996). The role of collaborative dialogue in teacher education. In D. Freeman \& J.C. Richards (Eds.), Teacher learning in language teaching. pp. 260 -280. Cambridge: Cambridge University Press.

Baroody, Alison E.; Diamond, Karen E. (2012). Links among Home Literacy Environment, Literacy Interest, and Emergent Literacy Skills in Preschoolers at Risk for Reading Difficulties. Topics in Early Childhood Special Education. Journal Articles, 32(2).

Cramer, E. D. (2010). Co-Teaching. Teaching and Teacher Education, (2007), 560-564.

Cook, L. \& Friend, M. (2010). The state of the art of collaboration on behalf of students with disabilities. Journal of Educational and Psychological Consultation, 20, 1-8.

Friend, M., \& Cook, L. (1992). The new including: How it really works. Instructor, 101(7), 30-36.

Laila Hairani Abdullah Sanggura (2008). Buku Panduan Kursus Pemantapan Pelaksanaan Kurikulum Pendidikan Islam KBSR. Institut Perguruan Bahasa-Bahasa Antarabangsa

Mohd Asnorhisham Adam, Abdul Rahim Hamdan, Muhamad Khairul Anuar Hussin. 2018. Co-Teaching Approach of Special Remedial Teacher and Malay Literacy Teacher in LINUS Program. Proceedings Of New Academia Learning Innovation (Nali) Symposium 2018.

Mohd Asnorhisham Adam \& Abdul Rahim Hamdan (2017). Komuniti Pembelajaran Profesional: Pengajaran Kolaboratif (Co-Teaching) Terhadap Penguasaan Literasi Bahasa Melayu Murid dibentangkan dalam Seminar Pendidikan Kebangsaan 2017. Johor, 23-24 September.

Mohd Asnorhisham Adam \& Abdul Rahim Hamdan (2016). Pendekatan Pengajaran Kolaboratif Terhadap Penguasaan Menulis Literasi Bahasa Melayu Murid Kertas dibentangkan dalam Seminar Penyelidikan Darul Aman (SEDAR) 2016. Kedah, 28 September.

Mohd Asnorhisham Adam \& Abdul Rahim Hamdan (2015). Isu Pendekatan Pengajaran Kolaboratif Terhadap Pemulihan Literasi Bahasa Melayu Kertas dibentangkan dalam Proceeding 2nd International Education Postgraduate Seminar (IEPS2015).

Nunan, D. (1992). Collaborative language learning and teaching. Cambridge: Cambridge University Press.

Zamri Mahamod (2012). Inovasi P\&P dalam Pendidikan Bahasa Melayu. Tanjung Malim, Perak: Penerbit UPSI 